This item was submitted to Loughborough's Research Repository by the author.

Items in Figshare are protected by copyright, with all rights reserved, unless otherwise indicated.

\title{
The idea of philosophical sociology
}

\section{PLEASE CITE THE PUBLISHED VERSION}

http://dx.doi.org/10.1111/1468-4446.12077

\section{PUBLISHER}

Wiley (@ London School of Economics and Political Science)

\section{VERSION}

AM (Accepted Manuscript)

\section{PUBLISHER STATEMENT}

This work is made available according to the conditions of the Creative Commons Attribution-NonCommercialNoDerivatives 4.0 International (CC BY-NC-ND 4.0) licence. Full details of this licence are available at: https://creativecommons.org/licenses/by-nc-nd/4.0/

\section{LICENCE}

CC BY-NC-ND 4.0

\section{REPOSITORY RECORD}

Chernilo, Daniel. 2019. “The Idea of Philosophical Sociology”. figshare. https://hdl.handle.net/2134/23156. 


\title{
The Idea of Philosophical Sociology $y^{1}$
}

(forthcoming in British Journal of Sociology, 2014)

Daniel Chernilo*

\begin{abstract}
This article introduces the idea of philosophical sociology as an enquiry into the relationships between implicit notions of human nature and explicit conceptualizations of social life within sociology. Philosophical sociology is also an invitation to reflect on the role of the normative in social life by looking at it sociologically and philosophically at the same: normative selfreflection is a fundamental aspect of sociology's scientific tasks because key sociological questions are, in the last instance, also philosophical ones. For the normative to emerge, we need to move away from the reductionism of hedonistic, essentialist or cynical conceptions of human nature. Sociology needs equally to grasp the conceptions of the good life, justice, democracy or freedom whose normative contents depend on more or less articulated conceptions of our shared humanity rather than on strategic considerations. The idea of philosophical sociology is then sustained on three main pillars and I use them to structure this article: (1) a revalorization of the relationships between sociology and philosophy; (2) a universalistic principle of humanity that works as a major regulative idea of sociological research, and; (3) an argument on the social (immanent) and pre-social (transcendental) sources of the normative in social life. As invitations to embrace posthuman cyborgs, nonhuman actants and material cultures proliferate, philosophical sociology offers the reminder that we still have to understand more fully who are the human beings that populate the social world.
\end{abstract}

Keywords: Sociology; philosophy; normativity; humanism; human nature; universalism

Last revision: 20 January 2014

8810 words

* Reader in Social and Political Thought, Loughborough University. 
The crisis of trust in several of our major social institutions over the past few years put puzzling questions to sociology. The press, the police, parliament, the Catholic church, banks and rating agencies are all functionally specific and, because of that, they are entrusted with the protection and indeed promotion of values that are central to their societal contribution: independent and trustworthy information, civil protection, representation and decisionmaking, moral guidance, safeguarding our private assets. In most cases, the procedures that should have prevented institutional misbehaviours were in place and were well known by the individuals concerned. Citizens and social scientists are equally concerned with why the values that society reasonably expected were being protected were rather being knowingly eroded by the guardians themselves.

Rather troublingly for us in sociology, however, these are not instances of anomie, dedifferentiation or iron cages. As I see it, our challenge is twofold. First, one underlying common theme to all these crises refers to the problematic location of the normative in social life. They demonstrate that, despite its fragility, the normative is not mere idealistic talk because the functional performance of these institutions was undermined by the neglect of their normative duties to the rest of society. The normative is not the central sphere of social life - it arguably never was - but nor is it possible to conceptualize the social without it. Sociology is surely not responsible for what happened even if its moralism and uncritical advocacy is highly frustrating at times. Yet we still need to explore whether sociology may have unwittingly contributed to it with a depiction of the social world in which normative ideas play no role; a representation of the social that has been emptied of all normative orientations: the atrophy and hypertrophy of the normative are equally dangerous. The second question also refers to the philosophical infrastructure of sociological thinking; in this case, how can our explanations connect institutional failings with the actions and practices of individual media editors, members of parliament, police officers, priests and traders for whom temptations were just too great to resist. To an extent, this is surely related to the perennial debate between structure and agency in sociology. But our ability to explain the relationships between individual actions and institutional failings still needs to be traced back to implicit conceptions of human nature that remain in place inside sociological accounts. These two questions, values and human nature or, as I rather discuss them below, the sources of the normative in social life and a principle of humanity, are central to this article and its idea of philosophical sociology.

The status of our shared humanity has of course been a major topic of debate in the Western tradition of social and political thought. If we look only at the twentieth century, World War II marks a conventional turning point: on the one hand, the claim that only hypocrisy is involved in invoking humanity as a higher moral notion, as apparent in Carl Schmitt (2007), Martin Heidegger (1977) and, all political differences notwithstanding, also in Jean-Francois Lyotard (1993); on the other hand, Karl Jaspers (2001) and Hannah Arendt's (1998) admission that appeals to humanity failed miserably to prevent war crimes but that they none the less remain a fundamental resource of our normative imaginary. More recent debates inside sociology also show an interest in the status of the idea of humanity, with its focus now being 
on how (bio)technologies are transforming the makeup of our species in both theory and practice (Fuller 2011; Latour 1993; Rose 2013); indeed, similar questions have been equally raised in methodologically driven debates (Adkins and Lury 2009; Back 2012; Back and Puwar 2012). I share their concern that we need more and better sociology and their view that this requires an explicit unpacking of the wider ontological and political implications of actual social scientific work. More problematic, it seems to me, is their premature embracing of post-social and indeed post-human standpoints. I should rather suggest that we are not in a position to make such claims not least because we still do not fully understand the role that ideas of humanity and human nature have actually played within sociology. In turn, this exploration may help us account for sociology's difficulties in understanding the normative.

The idea of philosophical sociology seeks to elucidate the relationships between implicit notions of human nature and explicit conceptualizations of social life within sociology and argues that a normative vocation for sociology emerges out of implicit presuppositions about the shared humanity of human beings to be found inside sociological theorizing. Philosophical sociology reflects on the intractable centrality of the normative in social life by looking at it sociologically and philosophically at the same: the questions that matter to sociologists are always, in the last instance, also philosophical ones. Let me briefly introduce the main tenets of the idea of philosophical sociology through three interrelated propositions. These then organize the bulk of my exposition below.

1. The relationships between sociology and philosophy. The idea of philosophical sociology builds upon a series of interventions over the past one hundred years. It takes the history of ideas seriously and argues that attempts at historical selfclarification are essential (Gouldner 1965; McCarthy 2003). Yet this is not only an exercise in historical precedence because, in order to be truly sociological, they require substantiation vis-à-vis contemporary concerns. An additional consequence of this is that claims to novelty are neither actively sought nor automatically accepted as criteria of explanatory success; the current obsession with novelty, innovation or radical epochal changes may have undermined our actual ability to understand contemporary social transformations (Chernilo 2007a).

2. The principle of humanity. As it concentrates on explaining social life as an autonomous and emergent domain, ideas of human nature have remained largely underexplored within sociology. Human nature is treated as a metaphysical residue that ought to be definitively transcended and yet presuppositions about human nature remain widely present in contemporary sociology as it is actually practised (Leahy 2012). Not all conceptions of human nature are equally fit for the purposes of sociological work, however, so my claim is that sociology's principle of humanity must be wholeheartedly universalistic in orientation. Below I will then contrast substantive and teleological ideas of human nature, which tend to be reductionist, against a more abstract counterfactual principle of humanity that works as a key regulative idea in sociology. 
3. The dual social and pre-social sources of the normative in social life. Sociology's perennial normative concerns are a direct result of its principle of humanity; we constantly go back to the consequences of human action on human beings, to the impact of social institutions on future developments of human life. In order to understand the normative, we need to treat it sociologically and philosophically at the same time: the normative is human-made and socio-historically changeable, thence its fully immanent quality, but it is also pre-social, and thus quasi-transcendental, because a principle of humanity that remains largely untouched by social forces is a condition of possibility of conceptualizing social life.

\section{I.}

The idea of philosophical sociology that this paper delineates seeks to delimit further a rich history of interconnections between sociology and philosophy over the past century. It does so from the point of view of sociology, and we can distinguish three strategies to look at their interrelationships. A first positivist path understands the philosophical tradition as sociology's pre-scientific heritage, whereas its future belongs to empirical and scientific work. Within the classical cannon this attitude is arguably best represented by Durkheim who, to be sure, engaged extensively in philosophical speculation and argued that a strict separation between sociology and philosophy was itself a philosophical proposition that was ultimately impossible (Durkheim 1960, 1982). But the key feature of this standpoint is that, however important, the engagement with philosophical sources is not a sociological task sensu stricto (Luhmann 1994; Merton 1964). A second strand is constituted by explicit attempts at epistemological self-clarification. An argument that we can trace back to Weber's methodological debates, the focus here is on elucidating the logic sociology's scientific arguments (Weber 1949). All such debates as idealism $\mathrm{v}$ materialism, individualism $\mathrm{v}$ collectivism, or realism $\mathrm{v}$ constructivism, belong in this category, and we may equally include here sociological meta-theory and more historicist accounts of the history of sociology that are written in order to illuminate its wider cognitive commitments (Benton 1977; Levine 1995; Ritzer 1988). The third approach is closer to social philosophy and uses the philosophical tradition to clarify sociology's normative motifs (Ginsberg 1968; Hughes 1974). Marx's (1975) influence over the future development of sociology is arguably paradigmatic of this kind of engagement, as apparent in how twentieth-century critical theory views the reconfiguration of normative questions as philosophy's key contribution to scientific sociology (Adorno 2000; Habermas 1974; Marcuse 1973), but it is also available to 'nostalgic' or conservative positions (Nisbet 1967; MacIntyre 2007). These three approaches on the relationships between philosophy and sociology may not exhaust all options but capture the most salient sociological attitudes. Philosophical sociology takes something from all three positions: it contributes to sociology's scientific project by keeping normative and empirical claims separate while in constant interplay (versions 1 and 2) and also to sociology's philosophical infrastructure because sociological enquiry is always susceptible of further normative scrutiny (version 3 ). 
My use of philosophical sociology here has little to do with the application of network analysis to intellectual history, as in Randall Collins's Sociology of Philosophies (Collins 1998). Rather, it is inspired in the more general idea of philosophical anthropology, which can be conventionally defined as a systematic inquiry 'general concepts' of humanity and our human properties (Hacker 2010). ${ }^{2}$ Philosophical sociology is however different from philosophical anthropology in that it seeks to unpack the relationships between mostly implicit conceptions of human nature and sociological conceptions of the social in order to reflect on the problem of the normative in social life. It is a philosophically informed form of sociology rather than a strictly normative approach or a reflection on the social conditionings of philosophical enquiry. $^{3}$

The idea of philosophical sociology achieved some modest notoriety in German sociology at the turn of the twentieth century. In the context of a discipline that was still intellectually and institutionally in the making, philosophical sociology was never intended to replace empirically minded social research. Rather, it was meant to clarify the presuppositions that were constitutive of, yet not directly central to, the scientific establishment of sociology. In his lecture at the first German sociology conference in 1910, Ferdinand Tönnies defined it as an enquiry into the logical organization of sociological concepts both inside sociology and in its relationships with other fields. Given its historical roots in philosophy, moreover, modern sociology was seen as a response to normative concerns in contemporary society and thus should remain fundamentally connected to questions about the 'ethical and good conduct of life' (Tönnies 2005: 57). He then argues that sociology must hold on to the invitation of the Oracle of Delphi - know thyself: sociology should become 'the impartial attempt to do justice to this commandment' (Tönnies 2005: 72). This early reference to philosophical sociology in Tönnies is thus partly epistemological and partly normative: it asks how sociological knowledge is being construed while it simultaneously makes the reflexive motto of knowing oneself essential for sociology's normative contribution to society. ${ }^{4}$

Georg Simmel also took up the idea of philosophical sociology as part of his well-known Kantian interrogation into the 'transcendental' presuppositions that make society possible (Simmel 1909). But Simmel equally suggested that there is a second metaphysical dimension to philosophical sociology: in order to move forward as a science, sociology must be prepared to overcome the restrictions that emerge from the slow pace at which all scientific contributions actually evolve. For sociology to become truly meaningful in wider public debates, it needs to move faster and more radically than science. It is only thanks to this work of genuine philosophical anticipation, argues Simmel, that we endow social phenomena with cultural significance. The most pressing sociological questions are precisely those for which exclusively scientific answers are evidently insufficient:

Is society the purpose of human existence, or is it a means for the individual? Does the ultimate value of social development lie in the unfolding of personality or of association? Do meaning and purpose inhere in social phenomena at all, or exclusively in individuals? (Simmel 1950: 25) ${ }^{5}$ 
Simmel and Tönnies thus share epistemological and normative motifs for the project of philosophical sociology but they sought neither undermine scientific sociology nor turn it into sociology's philosophical sublation.

Arguably the most consequential intervention in this early delimitation of philosophical sociology comes from Karl Löwith's Max Weber and Karl Marx. First published in 1932, it contends that both writers successfully brought together the two intellectual genres of (venerable) philosophy and (novel) social science. In empirical terms, Weber and Marx were equally interested in capitalism and offered radically different interpretations of its emergence and functioning. But there is another layer to their writings that for Löwith is more significant and where striking commonalities become apparent: the core 'of their investigations is one and the same (...) what is it that makes man "human" within the capitalistic world' (Löwith 1993: 42-3). This anthropological enquiry was surely not the explicit goal of either writer but therein lies none the less 'their original motive' (Löwith 1993: 43). Weber and Marx offer a new kind of intellectual enquiry that is, simultaneously, empirically informed and normatively oriented, and this is precisely what makes them 'philosophical sociologists' (Löwith 1993: 48). It is through the combination of scientific and philosophical approaches that they addressed fundamental intellectual questions: the interplay of material and ideal factors in human life, the immanent and transcendental condition of historical time, the relationships between social action and human fate, the disjuncture between existential concerns we all share as human beings and our particular socio-historical contexts. Philosophical sociology becomes then a programme in which sociology's most fundamental scientific challenge, the understanding of modern capitalism, is only possible on the basis of a philosophical quest for a principle of humanity that is fundamentally normative.

\section{II.}

Löwith's interest in this connection between general theories of modern society and philosophical ideas of humanity and human nature within sociology is largely though not wholly exceptional. ${ }^{6}$ Indeed, one of sociology's early motifs was the critique of previous 'metaphysical thinking' and references to the human in the singular were precisely the kind of burden that sociology was meant to leave behind; ideas of humanity and human nature seemed to undermine sociology's strong case for the autonomy of social relations as a legitimate field of enquiry (Chernilo 2013, Manent 1998). There is no definitive solution to these challenges because, at the same time as a universalistic principle of humanity is a condition of possibility of sociological explanations - only human beings are able to create and recreate society in all times and places and all human beings have this potential - the status of that shared humanity remains philosophically and normatively problematic. ${ }^{7}$

Ralf Dahrendorf's essays on Homo Sociologicus and Sociology and Human Nature, first published in 1957 and 1962 respectively, mark a turning point in our reconstruction (Dahrendorf 1973). The term philosophical sociology does not figure centrally in his texts but he explicitly focuses on the problem of human nature in sociology. Homo sociologicus, 
contends Dahrendorf, is American sociology's key contribution to the establishment of truly a scientific sociology - similar, indeed, to what homo oeconomicus had already done for economics. Stable and predictable role-conforming behaviour is sociology's representation of that specific aspect of human life that constitutes its particular subject matter: '[a]t the point where individual and society intersects stands homo sociologicus (...) To a sociologist the individual is his social roles' (Dahrendorf 1973: 6-7). He argues that, in explicitly unpacking homo sociologicus, sociology moves away from metaphysical reflections and fully separates its descriptive and normative concerns: homo sociologicus is explicitly not a full account of human nature. Rather, by concentrating only on empirically observable behaviour, sociology renews its scientific vocation in terms of 'powerful explanatory theories of social action'. In turn, this will allow sociology to leave behind the utopian project of 'describing the nature of man accurately and realistically' (Dahrendorf 1973: 76). But what is gained in scientific precision and predictive power is for Dahrendorf crucially lost in terms of normative purchase. The depiction of modern society must include such issues as conformism, passive adaptation to mass-production and the risk of totalitarianism, all of which point to problem of modern alienation in ways that homo sociologicus simply cannot grasp: '[s] ociology has paid for the exactness of its propositions with the humanity of its intentions, and has become a thoroughly inhuman, amoral science' (Dahrendorf 1973: 59). The difficulty he acknowledges but ultimately cannot solve is that homo sociologicus allows us to explore conformism as a key aspect of social life only by simultaneously precluding sociology from exploring human beings' ability to resist and overcome such conformism: explanatory success is paid at the price of normative impotence.

Instead of defeatism, the consequence I should like to draw from this is that not all conceptions of humanity or human nature are equally fit for purpose for a strong sociological programme. Indeed, we observe at least three main ways in which conceptions of the human have actually operated in sociology's history. I call them substantive, teleological, and counterfactual.

Substantive. A first group of ideas of human nature to be found in sociology derive rather directly from philosophy. These are conceptions that first developed in Western philosophy and have then permeated modern social sciences (Trigg 1999). I cannot unpack precise combinations between ideas of human nature and conceptualizations of social relations here, but some connections are readily available and illustrative my point:

- Marxism: an idea of the material reproduction of human life in which changes in how human labour is historically actualized lead to the rise of different modes of production and changes in the conditions of human exploitation;

- Psychoanalysis: the sexual drives that conform our deep personality-structures account for the establishment of moral taboos and institutional regulations that are key components of social life; 
- Utilitarianism: On the basis of our organic disposition to seek pleasure and avoid discomfort, maximizing calculations are central to the establishment of all kinds of social arrangements.

- Theories of power: our subjectivity is the result of struggles and forms of domination to such a large extent that all forms of social interaction are in effect conflictive;

- Theories of language: human communication is the fundamental attribute of our species, so social institutions can be assessed on the basis of how they prevent or promote freer forms of human communication.

All these notions of human nature uphold some kind of universalistic orientation: human beings are all equally endowed with that key attribute through which social life is created and recreated. More problematic is however the conflation between the social and the human: power, labour or language becomes both the key attribute of our shared humanity and of social life itself. There is also the risk that substantive ideas of human nature are turned into reductionist accounts of social life so that, rather than an abstract principle of humanity, we may end up with monist accounts of human nature.

Teleological. The history of sociological thinking shows the recurrence of evolutionist, modernizing, historicist and dialectical approaches in which teleology play a major role (Nisbet 2009). Ideas of human nature are here defined less in terms of a single universal feature and more in relation to the historical unfolding of certain tendencies that will lead to the full development of our human properties and to the establishment of a progressive social order. Teleological arguments may have lost a great deal of their old appeal, but one of their key contributions that remains is how they highlight the tension between the 'transcendental' aspect of all ideas of history - how history presupposes some sense of order - and the 'immanence' or contingency that is intrinsic to socio-historical trends and events: all sociological conceptions of historical change have to be able to accommodate both planes (Blumenberg 1983; Koselleck 1989; Löwith 1964). The reductionist universalism that was still available to substantive ideas of human nature is now eroded further because whole categories of human beings - Jews, Slavs, slaves, blacks, women, children - have been placed outside the human family because they were deemed 'unable' to flourish or to 'keep up' with historical developments (Edelstein 2009; Fine forthcoming).

Counterfactual. A third possibility, and the one favoured by philosophical sociology, is to conceive the idea of humanity as a major counterfactual inside sociology. Same as regulative ideas, counterfactuals do involve some substantive reference, but a key feature is that rather than being 'mere constructs' counterfactual ideas are 'operatively effective' (Habermas 2003: 107-8). ${ }^{8}$ Let me now briefly discuss two cases in which a sociological principle of humanity is in action.

In his late Action Theory and the Human Condition, Talcott Parsons reflects explicitly on the problem of our shared humanity. There, Parsons applied his well-known paradigm of the four functions AGIL, which he had proved for the conceptualization of all levels of reality (natural, 
personal, social and cultural), to the understanding of our fundamental human attributes. In other words, AGIL must now work also from an 'anthropocentric point of view' that is able to include the generic point of view of the human species as a whole as well as the perspective of the concrete human individual' (Parsons 1978: 361, 391). This principle of humanity explicitly differentiates between social and human aspects, as it focuses on those 'assumptions of social ordering at the human level' (Parsons 1978: 371). And in addition to conceptualizing the connections between social relations and human attributes, Parsons's definition avoids reductionism thanks to the multi-layered nature of AGIL. Language is central for the integrative function (I), and a sense of 'the transcendental', a concern with the meaning of life, is central for the latency function (L). But we are not purely ideal beings, of course, so his conceptualization of the human condition also has an external locus: the organic system of our personality, which is central for the function of goal attainment (G), and the physico-chemical constitution with which humans adapt to the natural environment (A). This multidimensional approach to the principle of humanity is an insight that we ought to retain because, on the one hand, it unpacks the universalistic presuppositions about our shared humanity as both material and ideal beings and, on the other hand, it connects without eliding our understandings of the human and the social. Indeed, the telic dimension explains the fundamental human ability to think and represent ourselves by imagining a potentially different state of affairs; it grasps the specifically human skill of temporarily suspending the self-centred standpoint that characterizes all forms of life and with the help of which we construe justifications that do not recourse to the egocentric point of view.

My second reference point is Margaret Archer's explicit call for the clarification of contemporary sociology's principle of humanity. In her view, this is firstly and fundamentally related to a continuous sense of the self that is both 'prior' and 'primitive' to our 'sociality' (Archer 1995: 284). A second feature of this principle of humanity is our normative imagination: 'human beings have the unique potential to conceive of new social forms' (Archer 1995: 289). And there is also a third one: all forms of understanding in the social sciences require that 'they', the subjects of our studies, and 'we' the researchers, share key human attributes as members of the same species. However tentative, and regardless of whatever may get lost in the process, our work as social scientists depends on how human experiences can be understood, shared and then communicated to others who have never been there - it favours the transmissibility of human experiences across highly heterogeneous historical and socio-cultural settings. This principle of humanity has normative implications built into it, moreover, because it allows us

to judge whether social conditions are dehumanizing or not. Without this reference point (...) then justification could be found for any and all political arrangements, including ones which place some groups beyond the pale of 'humanity'. (Archer 1995: $288-9)^{9}$

Depending on how we understand our scientific tasks we may or may not seek to spell out these normative consequences, but they are integral to the actual functioning of sociology. As 
a regulative idea, this principle of humanity makes apparent that sociological research treats all human beings as equally equipped for the creation and recreation of social life and this is precisely why it matters so much that we do not choose, nor can we alter at will, the fundamentally unequal and socially created settings within which we exercise these human capabilities. Sociology seeks to understand experiences of change, variability and conflict by looking at the different ways in which social life is and has been organized. But we only recognize different social settings as social because we are able to trace them back to our shared human belonging: in any of the sociological stories we tell, the subjects out there could well have been us. It is human rather than socio-cultural empathy that makes sociological work possible.

In summary, then, sociology's principle of humanity upholds a universalistic orientation in three planes: conceptually, as all human beings are equally able to create and recreate social life; methodologically, as social scientific knowledge is susceptible of translation across different cultural and historical contexts, and; normatively, as it offers the opportunity to assess different social and institutional practices as either favouring or undermining the development of those fundamental qualities that are constitutive of our shared humanity. The principle of humanity is the condition of possibility of sociological knowledge; it is sociology's own regulative idea (Chernilo 2007b).

\section{III.}

Sociology's principle of humanity makes apparent the tension between its explicit commitment to the largely constructed character of social reality, with its emphasis on historical change, socio-cultural variability and normative disagreement, and the mostly implicit requirement that the unity human species is in fact pre-social. If sociology's cognitive structure depends equally on the emergent status of the social and on a principle of humanity that is independent from social forces, then this clarification contributes as much as challenges sociology's cognitive status.

Reinhard Bendix has argued in this connection that, as they progress and become increasingly successful in advancing empirical knowledge about society, '[t]he sciences of men have grown together with a sceptical view of human nature, and the latter raises questions about the utility of social knowledge' (Bendix 1970: 58). The more insightful social scientists become in understanding social reality, the harder it is to continue believing in its perfectibility; the more we learn about how society works, the more we realise how difficult it is to change it. Awareness of our own human fallibility undermines the collective trust in reason as the key human capacity that can lead to social improvement. Bendix then speaks of a tension between the explicit justifications with which the social sciences seek legitimacy, the promise that they are able to contribute to social betterment, and a major undesired side-effect of social research; namely, the fact that human nature is ultimately intractable vis-à-vis social life: social reality does not change according to the predictions of social scientists and human nature hardly changes at all. Bendix (1970: 11) anticipated the irrationalist challenge that has since become mainstream in sociology: the view of human nature as something that cannot be 
socially altered (at least not at will), has been wrongly turned into reductionist accounts of social life, scientific knowledge and indeed our shared humanity itself. We mistake the relative independence of human nature vis-à-vis social factors for reductionist ideas that only consider humanity's irrational elements and we end up with conceptions of both the social and the human that are wholly devoid of normative content. This irrationalism is unable to account for its own position and leaves no space for understanding the normative as a relevant aspect of social life itself.

Contemporary sociology is arguably split between a non-normative understanding of the normative (Abend 2008; Elder-Vass 2010; Turner 2010) and militant positions that are highly normative in orientation (Burawoy 2005). ${ }^{10}$ Philosophical sociology argues that a nonnormative understanding of the normative solves only half of the problem as it only accounts for its socially construed aspect, but it is also different from militant sociology because the normative is apparent and poses no intellectual challenge: the former reduces the normative to what people think the normative is and the latter anticipates rather than explicitly pursues normative self-clarification. Either way, it seems fair to say that mainstream sociology has grown sceptical of its own ability to think the normative as normative. Somewhat paradoxically, through explicitly anti-positivistic arguments, constructivism, postmodernism, postcolonialism and globalism all contribute to one key goal that the traditional positivistic agenda was never fully able to accomplish: a sense that our disciplines are in fact ill-equipped to conceptualize, let alone advance or criticize, normative questions. The current situation goes beyond the wildest dreams of traditional positivism, however, because while for them normative challenges are real though alien to proper scientific research, our contemporary situation appears to be an ontological amplification of positivism: the social itself has been emptied of any normative dimension. We can rephrase this in terms of the Weberian problem of value-free social science. For Weber, our scientific commitments do not save us from having to decide what we ought to do in social and political life because the modern world is populated by too many value orientations. The contemporary claim, on the contrary, is that there are no values whatever left in the social world, which is thus reduced to power struggles, strategic bargaining and identity politics. Accepting the difficulty of making normative decisions and then calling for personal responsibility - Weber's dilemma - is altogether different from (let alone more challenging than) strategically seeking for any available argument to defend whatever is good for us.

By far the most influential position in contemporary sociology is that of Pierre Bourdieu. ${ }^{11}$ Committed as he is to political causes, Bourdieu engages constantly with normative questions. But normativity is not conceptualized sociologically, it is not included as an actual dimension of the social world because conflict, power and struggles give full shape to his ontology of the social: '[t]he particularity of sociology is that it takes as its object fields of struggle - not the field of class struggle but the field of scientific struggles itself. And the sociologist occupies a position in these struggles' (Bourdieu 1994: 10). The normative motif of his militant sociology is that the interests of less powerful actors ought to be favoured against those of more powerful ones. The sociologist can be seen as the reflexive amplifier with the help of which 
subordinate actors get their interest advanced wherever and whenever this is needed. The problem is not at all with Bourdieu's political options but with the disregard for the need of normative self-clarification in social life (Honneth 1986). Indeed, in terms of conceptions of human nature, Bourdieu readily accepts that sociology

inevitably appeals to anthropological theories (...) it can make real progress only on condition that it makes explicit these theories that researchers always bring in (...) and which are generally no more than the transfigured projection of their relation to the social world. (Bourdieu 1994: 19)

As we explore further on the connection between conceptions of the social and of human nature within Bourdieu's sociology, all we obtain are reductionist notions of interests and permanent struggle. These then lead to an irrationalist conception of the social:

there is a form of interest or function that lies behind every institution or practice (...) the specifically social magic of an institution can constitute almost anything as an interest and as a realistic interest, i.e. as an investment (both in the economic and the psychoanalytic senses), that is objectively rewarded, in the more or less long term, by an economy. (Bourdieu 1994: 18)

Let me now come back to the crises that I mentioned in the opening paragraphs to this piece. Empirically, Bourdieu's sociology predicts that there will always be winners and losers (remember: interests lie behind every institution and practice); normatively, it anticipates on which side our loyalties should be. Powerful actors take advantage of their privileged positions because this is what we would all do (everyone has ever done?) under similar circumstances. If power-relations change, others will come in their stead, do similar things, and eventually fall for similar vices. Bourdieu's sociology may contribute to the structural account of these crises but the approach remains insufficient because social phenomena should not always and necessarily be understood in terms of winners and losers. Furthermore, he is blind to the key issues of what is normatively at stake and what role do normative factors play in these crises. Indeed, this inability goes beyond Bourdieu's sociology, as irrationalist conceptions of human nature that centre on our innate impulses, primordial authenticity and strategic bargaining are equally unable to grasp how normative questions come into play in society. This 'normative-less' depiction of social life is sociology's unintended contribution to our contemporary social malaise; it is sociology's very own selffulfilling dystopia: we do not take normative factors into account as part of what we have to explain sociologically because our ontologies of the social allow for no concept of the normative. An explanation of contemporary crises must include their normative aspects, but for the normative to emerge as an autonomous aspect of social life we require a nonreductionist principle of humanity.

Let me very briefly substantiate further some of these programmatic arguments in relation to the emergent field of the sociology of human rights (Cushman 2012). Indeed, historically, the 
sociology of human rights still needs to explore more fully its connections to the enlightenment and the natural law tradition (Fine 2009). And this is sociologically important in terms of the clarification of the conceptions of human dignity that underpin human rights (Habermas 2010) and of the tensions between human rights and popular sovereignty as the co-original sources of modern normative legitimacy (Habermas 1996). We surely have to confront the relativistic challenge that comes from the fact that, as all social institutions, human rights are socially constructed (Anleu 1999; O'Bryne 2012). And there is also the problem of their insufficient practical purchase and only partial success in terms of their own normative standards (Morris 2010; Nash 2009). The key here is that the criticisms we raised against non-normative conceptualizations of the social apply equally to non-normative ideas of human rights; as they cannot be justified on purely particularistic grounds (Waters 1996), their universalistic justifications must become ever more sophisticated (Donnelly 2002; Young 2003). The contribution of philosophical sociology may lie here in unpacking the interconnections between their anthropological grounding in a principle of humanity that remains pre-social and their always-ambivalent social and cultural actualizations. In sociology, Bryan Turner has offered a principle of this kind: our bodily constitution and human frailty are the pre-social and universal dimensions of our shared humanity that can serve as the universalistic threshold against which to assess social institutions and thus ground human rights (Turner 1993, 2006). All across history and cultures, human beings develop a sense that certain practices and institutions cause human misery and, because of that, ought to be avoided and rejected (Moore 1972). Human rights are defined through a principle of humanity that articulates those transcendental or pre-social elements as they become actualized in various social settings; or, to put it differently, an immanent idea of social order requires a meaningful representation of its own internal transcendence: all individual human beings are equally endowed with the same human attributes, which are then unequally realized only in the social and cultural environments that humans create by their living together (Nussbaum 2006). The normativity of human rights can only be justified in relation to a universal but is lived and actualized in the particulars of our actually existing polities; their normativity is immanent because they are only exercised in society but it is also transcendental in terms of our innate ability to recognize others, and ourselves, as members of the same human species. The principle of humanity poses cognitive limits to how we explain society as well as normative limits to what is acceptable in society, it involves a tension between immanent justifications that make arguments rationally acceptable and the transcendental grounds that make them binding (Chernilo 2013).

\section{IV.}

I introduced the idea of philosophical sociology as an invitation to take up the challenge of further normative self-scrutiny as a permanent component of sociology's scientific tasks, so let me conclude with three additional justifications for this central claim. First, as said, what turns the workings of dysfunctional institutions into social crises is not only their material consequences but also their normative deficits. Understanding the eroded legitimacy of these institutions is a central task for sociological research, but this can only be done if the normative is explicitly conceptualized as normative. One key lesson from Hannah Arendt's 
(2006) chilling depiction of Adolf Eichmann's trial is that there is no radical ontological break between perpetrators and victims: some may have acted differently under similar circumstances but many may not. Reductionist conceptions of human nature make it easier to deflect attention from what is normatively at stake: why and how other human beings acted under particularly difficult circumstances. For the normative to emerge, we need sociology to observe what else, apart from hedonistic, self-centred or cynical considerations are at stake for social actors: even if universalism is not all we need in order to understand the normative, the normative cannot be conceptualized without a universalistic conception of human beings. Secondly, normative considerations become sociologically visible as we interrogate why certain interests are important for actors themselves. We must unpack what is normatively behind their options in terms of their conceptions of the good, justice, democracy or freedom. Thus, for instance, nationalist movements may justify their separatist claims on democratic as well as on xenophobic grounds, and this kind of normative clarification is central to sociological enquiry (Chernilo 2011; Mann 2005). Modern grammars of justification are no mere rationalizations of material interests and power positions: they are based on ideas of common humanity that connect to socially differentiated conceptions of justice (Boltanski and Thévenot 2006). Things that matter to people are important to them subjectively because they speak to the shared potentials and limitations of all human beings (Sayer 2011). Thirdly, we human beings have a shared ability to represent ourselves within the world we live in by conceiving new institutions and rules, by anticipating ideal states of affairs that we know all too well that may never be realized. But for us to conceptualize this, we still have to question the culturalist and constructionist taboos of contemporary sociology: human beings have a transcultural and transhistorical sense of 'self-transcendence': we come to terms with the world we live in by imagining that a better one is indeed possible (Joas 2000; Voegelin 2000). Social life unfolds as human beings negotiate what we want, can, and must do. A tensional relationship between desires, opportunities, and demands constitutes the plasticity that shall always remain problematic for the social sciences because it is a constitutive predicament of the human condition as simultaneously individual and social.

We do indeed need to reflect on post-human cyborgs, non-human actants, material cultures and biopolitical transformations, and we may eventually have to redefine our ontologies of the human and the social accordingly. But philosophical sociology offers the reminder that, first, we still do not fully understand what human beings are vis-à-vis our conceptualizations of the social and, secondly, that all these insights matter on the basis of prior and systematic human intervention; we care about them because of their consequences on human and social life. The perennial tension between description and normativity in sociology is to be ultimately explained because we refer back to human actions and human consequences, to the curtailment or expansion of our human lives. Postmodernism, globalism and postcolonialism have all contributed to the political and epistemological de-centring of spurious universalistic claims. Yet as their arguments have been used and abused, their critique begins to look exhausted and inconsequential. If sociological critique is to live on, we need to reconsider rather abandon the question of universalism in the social sciences. Philosophical sociology is 
an invitation to try to understand more fully who are the human beings that populate the social world.

\section{Notes}

\section{${ }^{1}$ Acknowledgements}

My thanks to Rafael Alvear, Rodrigo Cordero, Dave Elder-Vass, Robert Fine, Ana Gross, Karen Lumsden, Aldo Mascareño, Paula Mena, Sabina Mihelj, Karen O’Reilly, Csaba Szaló, Cristian Tileaga and Frederic Vandenberghe for comments to previous versions of this piece and their encouragement to pursue this project.

2 The German tradition of philosophical anthropology is associated, in the 1910s and 1920s, with works by Ernst Cassirer and Max Scheler and, after World War II, with the names of Arnold Gehlen, Helmut Plessner and Helmut Schelsky. The difference between both generations is crucial, however: Cassirer and Scheler are committed to the universalistic tradition of the Enlightenment in a way that is alien to the second generation. See Honneth and Joas (1988), Heidegren (1997) and Magerski (2012) for further discussion.

${ }^{3}$ Another important source, which I cannot however pursue here, is Hans Jonas's $(2001: 83,92)$ idea of philosophical biology: i.e., the 'reunion', through a concept of freedom, of philosophical anthropology and a philosophy of nature. The importance of Jonas's work lies in that it explicitly accounts for the naturalistic presuppositions and implications of this line of enquiry.

${ }^{4}$ On Tönnies's vision of sociology as a dual normative and descriptive project, see Bond (2013).

${ }^{5}$ See, similarly, Harrington and Kemple (2012) discussion of Simmel's 'sociological metaphysics'.

${ }^{6}$ A notable exception is Dennis Wrong's work (1977: 55-70; 1994: 14-36, 70-109).

7 The recent postcolonial turn has made sociology aware that these are real difficulties (GutiérrezRodríguez, Botaca and Costa 2010). But if attached to the rejection of any normative value to a universalistic conception of humanity it leads to self-defeating consequences (Connell 2007).

8 On regulative ideas and ideals, see, paradigmatically, Kant (1973: 485-6). On how regulative ideals are effectively operative in social scientific and normative enquiry, see Emmet (1994).

${ }^{9}$ See Archer (2000) for further elaboration of these ideas.

${ }^{10}$ Hitlin and Vaisey's (2010) collection surveys this field with a view to redressing sociology's deficit in conceptualizing the normative.

11 As of 20 January 2014, Bourdieu is the most cited sociologist in Google Scholar with a score of over 319,000 citations. Marx and Weber come second and third, respectively, and their citations combined fall well short of Bourdieu's figure. 


\section{Bibliography}

Abend, G. 2008 'Two Main Problems in the Sociology of Morality', Theory and Society 37(2): 87-125.

Adkins, L. and Lury, C. 2009 'Introduction: What is the Empirical?', European Journal of Social Theory 12(1): 5-20.

Adorno, T. 2000 Introduction to Sociology, Cambridge: Polity Press.

Anleu, S. R. 1999 'Sociologists Confront Human Rights: The Problem of Universalism', Journal of Sociology 35(2): 198-212.

Archer, M. S. 1995 Realist Social Theory. The Morphogenetic Approach, Cambridge: Cambridge University Press.

Archer, M. S. 2000 Being Human. The Problem of Agency, Cambridge: Cambridge University Press.

Arendt, H. 1998 The Human Condition, Chicago: The University of Chicago Press.

Arendt, H. 2006 Eichmann in Jerusalem, London: Penguin.

Back, L. 2012 'Live Sociology: Social Research and its Futures', The Sociological Review 60(1): 18-39.

Back, L. and Puwar, N. 2012 'A Manifesto for Live Methods: Provocations and Capacities', The Sociological Review 60(1): 6-17.

Bendix, R. 1970 Embattled Reason. Essays on Social Knowledge, New York: Oxford University Press.

Benton, T. 1977 Philosophical Foundations of the Three Sociologies, London: Routledge and Kegan Paul.

Blumenberg, H. 1983 The Legitimacy of the Modern Age, Cambridge, Massachusetts: MIT Press.

Boltanski, L. and Thévenot, L. 2006 On Justification. Economies of Worth, Princeton: Princeton University Press. 
Bond, N. 2013 Ferdinand Tönnies' 'Community and Society'. Social Theory and Political Philosophy Between Enlightened Liberal Individualism and Transfigured Community, Berlin: LIT.

Bourdieu, P. 1994 Sociology in Question, London: Sage.

Burawoy, M. 2005 'For Public Sociology', American Sociological Review 70(2): 4-28.

Chernilo, D. 2007a A Social Theory of the Nation-State. The Political Forms of Modernity beyond Methodological Nationalism, London: Routledge.

Chernilo, D. 2007b 'A Quest for Universalism: Re-assessing the Nature of Classical Social Theory's Cosmopolitanism', European Journal of Social Theory 10(1): 17-35.

Chernilo, D. 2011 'The Critique of Methodological Nationalism: Theory and History', Thesis Eleven 106(1): 98-117.

Chernilo, D. 2013 The Natural Law Foundations of Modern Social Theory. A Quest for Universalism, Cambridge: Cambridge University Press.

Collins, R. 1998 The Sociology of Philosophies. A Global Theory of Intellectual Change, Cambridge, Massachusetts: The Belknap Press.

Connell, R. 2007 Southern Theory, Cambridge: Polity Press.

Cushman, T. (ed.) 2012 Handbook of Human Rights, London: Routledge.

Dahrendorf, R. 1973 Homo Sociologicus, London: Routledge and Kegan Paul.

Donnelly, J. 2002 Universal Human Rights in Theory and Practice, Ithaca, NY: Cornell University Press.

Durkheim, E. 1960 'The Dualism of Human Nature and its Social Conditions', in K. Wolf (ed.) Essays on Sociology and Philosophy, New York: Harper.

Durkheim E. 1982 The Rules of Sociological Method, New York: The Free Press.

Edelstein, D. 2009 The Terror of Natural Right. Republicanism, The Cult of Nature and the French Revolution, Chicago: The University of Chicago Press

Elder-Vass, D. 2010 The Causal Powers of Social Structures, Cambridge: Cambridge University Press. 
Emmet, D. 1994 The Role of the Unrealisable: A Study in Regulative Ideals. New York: St. Martin's Press.

Fine, R. 2009 'Cosmopolitanism and Human Rights: Radicalism in a Global Age', Metaphilosophy 40(1): 8-23.

Fine, R. forthcoming 'Cosmopolitanism and Anti-Semitism: On the Difficulties Created by the Janus-face of Universality', in A. Marinopoulou (ed.) On Cosmopolitan Modernity, London: Continuum.

Fuller, S. 2011 Humanity 2.0: What it Means to Be Human Past, Present and Future, Basingstoke: Palgrave

Ginsberg, M. 1968 Essays in Sociology and Social Philosophy, London: Penguin.

Gouldner, A. 1965 Enter Plato. Classical Greece and the Origins of Social Theory, London: Routledge and Kegan Paul.

Gutiérrez-Rodríguez, E, Botaca, M. and Costa, S. 2010 Decolonizing European Sociology. Transdisciplinary Approaches, Farnham: Ashgate.

Habermas, J. 1974 Theory and Practice, London: Heinemann.

Habermas, J. 1996 Between Facts and Norms, Cambridge, Massachusetts: The MIT Press.

Habermas, J. 2003 Truth and Justification, Cambridge, Massachusetts: The MIT Press.

Habermas, J. 2010 'The Concept of Human Dignity and the Realistic Utopia of Human Rights', Metaphilosophy 41(4): 464-80.

Hacker, P. M. S. 2010 Human Nature: The Categorical Framework, Oxford: Wiley-Blackwell.

Harrington, A. and Kemple, T. 2012 'Introduction: Georg Simmel's "Sociological Metaphysics": Money, Sociality and Precarious Life', Theory, Culture and Society 29(7/8): 7-25.

Heidegger, M. 1977 Basic Writings, London: Routledge

Heidegren, C-G. 1997 'Transcendental Theory of Society, Anthropology and the Sociology of Law: Helmut Schelsky - An Almost Forgotten Sociologist', Acta Sociologica 40: 269-90.

Hitlin, S. and Vaisey, S. (eds) 2010 Handbook of the Sociology of Morality, New York: Springer. 
Honneth, A. 1986 'The Fragmented World of Symbolic Forms: Reflections on Pierre Bourdieu's Sociology of Culture', Theory, Culture and Society 3(3): 55-66.

Honneth, A. and Joas, H. 1988 Social Action and Human Nature, Cambridge: Cambridge University Press.

Hughes, H. S. 1974 Consciousness and Society, Frogmore, Paladin.

Jaspers, J. 2001 The Question of German Guilt, New York: Fordham University Press.

Joas, H. 2000 The Genesis of Values, Cambridge: Polity Press.

Jonas, H. 2001 The Phenomenon of Life. Towards a Philosophical Biology, Evanston: Northwestern University Press.

Kant, I. 1973 Critique of Pure Reason, London: The Macmillan Press.

Koselleck, R. 1989 Critique and Crisis. Enlightenment and the Pathogenesis of Modern Society, Cambridge, Massachusetts: MIT Press.

Latour, B. 1993 We Have Never Been Modern, Cambridge, Massachusetts: Harvard University Press.

Leahy, T. 2012 'The Elephant in the Room: Human Nature and the Sociology Textbooks', Current Sociology 60(6): 806-23.

Levine, D. 1995 Visions of the Sociological Tradition, Chicago: The University of Chicago Press.

Löwith, K. 1964 Meaning in History, Chicago: The University of Chicago Press.

Löwith, K. 1993 Max Weber and Karl Marx, London: Routledge.

Luhmann, N. 1994 "'What Is the Case?" and "What Lies Behind It?" The Two Sociologies and the Theory of Society', Sociological Theory 12(2): 126-39.

Lyotard, J. 1993 The Inhuman: Reflections on Time, Cambridge: Polity Press

MacIntyre, A. 2007 After Virtue, London: Duckworth

Magerski, C. 2012 'Arnold Gehlen: Modern Art as Symbol of Modern Society' Thesis Eleven 111: 81-96.

Manent, P. 1998 The City of Man, Princeton, Princeton University Press. 
Mann, M. 2005 The Dark Side of Democracy. Explaining Ethnic Cleansing, Cambridge: Cambridge University Press.

Marcuse, H. 1973 Reason and Revolution. Hegel and the Rise of Social Theory, London: Routledge and Kegan Paul.

Marx, K. 1975 Early Writings, London: Penguin.

McCarthy, G. 2003 Classical Horizons. The Origins of Sociology in Ancient Greece, Albany: State University of New York.

Merton, R. 1964 Social Theory and Social Structure, New York: The Free Press.

Moore, B. 1972 Reflections on the Causes of Human Misery and Upon Certain Proposals to Eliminate Them, London: Allen Lane.

Morris, L. 2010 'Sociology and the Two Faces of Human Rights' Sociology Compass 4(5): 32233.

Nash, K. 2009 'Between Citizenship and Human Rights', Sociology 43(6): 1067-83.

Nisbet, R. 1967 The Sociological Tradition, London: Heinemann.

Nisbet. R. 2009 Metaphor and History, New York: Transaction.

Nussbaum, M. 2006 Frontiers of Justice. Disability, Mationality, Species Membership, Cambridge, Massachusetts: The Belknap Press.

O'Bryne, D. 2012 'On the Sociology of Human Rights: Theorising the Language Structure of Rights', Sociology 46(5): 829-43.

Parsons, T. 1978 Action Theory and the Human Condition, New York: The Free Press.

Ritzer, G. 1988 'Sociological Metatheory: A Defense of a Subfield by a Delineation of its Parameters', Sociological Theory 6(2): 187-200.

Rose, N. 2013 'The Human Sciences in a Biological Age', Theory, Culture and Society 30(1): 334.

Sayer, A. 2011 Why Things Matter to People. Social Science, Values and Ethical Life, Cambridge: Cambridge University Press. 
Schmitt, C. 2007 The Concept of the Political, Chicago, The University of Chicago Press

Simmel, G. 1909 'The Problem of Sociology', American Journal of Sociology 15(3): 289-320.

Simmel, G. 1950 'Fundamental Problems of Sociology (Individual and Society)', in K. Wolf (ed.), The Sociology of Georg Simmel, Glencoe, Illinois: The Free Press.

Tönnies, F. 2005 'Ways and Goals of Sociology', in C. Adair-Toteff, (ed.) Sociological Beginnings. The First Conference of the German Society for Sociology, Liverpool: Liverpool University Press.

Trigg, R. 1999 Ideas of Human Nature. A Historical Introduction, Oxford: Blackwell.

Turner, B. S. 1993 'Outline of a Theory of Human Rights', Sociology 27(3): 489-512.

Turner, B. S. 2006 Vulnerability and Human Rights, Pennsylvania: Penn State University Press.

Turner, S. 2010 Explaining the Normative, Cambridge: Polity Press.

Voegelin, E. 2000 'Order and History Volume IV. The Ecumenic age', in The Collected Works of Eric Voegelin Vol. 17, Columbia: University of Missouri Press.

Waters M. 1996 'Human Rights and the Universalisation of Interests: Towards a Social Constructionist Approach', Sociology 30(3): 593-600.

Weber, M. 1949 The Methodology of the Social Sciences, New York: The Free Press.

Wrong, D. 1977 Skeptical Sociology, London: Heineman.

Wrong, D. 1994 The Problem of Order. What Unites and Divides Societies, New York: The Free Press.

Young, T. R. 2003 'The Sociology of Human Rights', Humanity and Society 27(3): 295-312. 